\title{
POLA PENYAKIT KULIT NON-INFEKSI PADA ANAK DI POLIKLINIK KULIT DAN KELAMIN RSUP PROF. DR. R. D. KANDOU MANADO PERIODE 2009-2011
}

\author{
${ }^{1}$ Ananias Malak \\ ${ }^{2}$ Herry E. J. Pandaleke \\ ${ }^{2}$ Marlyn. G. Kapantow \\ ${ }^{1}$ Kandidat Skripsi Fakultas Kedokteran Universitas Sam Ratulangi Manado \\ ${ }^{2}$ Bagian Ilmu Kesehatan Kulit dan Kelamin Fakultas Kedokteran \\ Universitas Sam Ratulangi Manado \\ Email: anismalak18@yahoo.co.id
}

\begin{abstract}
Non-infectious skin disease is a skin disease that is not caused by pathogenic bacteria or by transmission. Many non-infectious skin diseases showed different manifestations in infants and children. This study aimed to obtain the patterns of noninfectious skin diseases in children at Dermatovenorology Department Prof. Dr. R. D. Kandou General Hospital period 2009-2011. This was a retrospective study. Data of the annual cases, gender, and ages were obtained from the medical records. From a total of 595 patients in 2009-2011 there were 323 (54.29\%) children with non-infectious skin diseases, females (167 patients, 51.70\%) were more frequent than males, and most commonly in the age group of 5 to14 years (59.13\%). Conclusion: Non-infectious skin diseases were still common in Dermatovenorology Department Prof. Dr. R. D. Kandou General Hospital period 2009-2011.
\end{abstract}

Keywords: non-infectious skin diseases, children

\begin{abstract}
Abstrak: Penyakit kulit non-infeksi adalah penyakit kulit yang tidak disebabkan oleh kuman patogen ataupun ditularkan. Banyak penyakit kulit non-infeksi memperlihatkan manifestasi yang berbeda pada bayi dan anak-anak. Penelitian ini bertujuan untuk mengetahui pola penyakit kulit non-infeksi pada anak di Poliklinik Kulit dan Kelamin RSUP Prof. Dr. R. D. Kandou Manado periode 2009-2011.Metode Penelitian dilakukan secara retrospektif pada pasien anak dengan penyakit kulit non-infeksi yang datang ke Poliklinik Kulit dan Kelamin pada tahun 2009-2011. Data diperoleh dari rekam medik mengenai jumlah kasus pertahun, jenis kelamin, dan umur. Hasil penelitian memperlihatkan dari sejumlah 595 kunjungan pada tahun 2009-2011 terdapat 323 (54,29\%) pasien anak dengan penyakit kulit non-infeksi, distribusi jenis kelamin memperlihatkan perempuan yang terbanyak 167 (51,70\%), dan ter banyak pada kelompok umur 5-14 tahun (59,13\%). Simpulan: Penyakit kulit non-infeksi masih sering dijumpai pada pasien anak di RSUP Prof. Dr. R. D. Kandou Manado.
\end{abstract}

Kata kunci: penyakit kulit non-infeksi, anak 
Penyakit kulit pada anak sering ditemukan dan dapat bersifat transien atau kronik dan rekuren. ${ }^{1}$ Penyakit kulit pada anak sering mempunyai manifestasi klinis, morfologi maupun tempat predileksi berbeda dengan yang terdapat pada penderita dewasa. Keadaan ini mungkin karena kulit pada anak-anak lebih tipis dan fungsinya belum berkembang lengkap seperti pada orang dewasa. ${ }^{2,3}$

Sebanyak 18 studi prevalensi populasi umum di Negara berkembang melaporkan angka prevalensi yang tinggi untuk penyakit kulit (21-87\%). Berikut ini gangguan yang paling sering pada anak-anak: dermatitis (73,46\%), sindrom hipersensitifitas (6,03\%), kelainan pigmen (4,23\%), kelainan papuloskuamosa (3,97\%). Data tersebut menunjukan angka penyakit dermatitis masih mendominasi atau yang paling sering terjadi pada anak-anak (WHO).

Di Indonesia sendiri dari data yang dilaporkan dari poliklinik kulit dan kelamin RSUD Dr. Soebandi Jember sejak januari 2001 sampai desember 2004, terdapat 3495 (11,66\%) pasien anak. Sedangkan di manado sendiri dari data yang di laporkan dari poliklinik kulit dan kelamin RSUP Prof. Dr. R. D. Kandou Manado sejak januari 2006 sampai desember 2008 dari total kunjungan 1351 pasien anak terdapat 780 pasien $(57,74 \%)$ dengan penyakit kulit non-infeksi. ${ }^{4}$

Tujuan penelitian ini untuk mengetahui pola penyakit kulit non- infeksi pada anak di poliklinik kulit dan kelamin RSUP Prof. Dr. R. D. Kandou Manado pada tahun 20092011.

\section{METODE PENELITIAN}

Penelitian ini dilakukan secara retrospektif dengan mengumpulkan catatan medic pasien anak dengan penyakit kulit non-infeksi yang dating berobat di poliklinik kulit dan kelamin RSUP Prof. Dr. R. D. Kandou Manado periode 2009-2011. Dilakukan pencatatan data mengenai jumlah kasus pertahun, jenis kelamin, dan umur.

\section{HASIL PENELITIAN}

Dari hasil evaluasi retrospektif yang dilakukan pada pasien anak di poliklinik kulit dan kelamin RSUP Prof. Dr. R. D. Kandou Manado selama 3 tahun, dari 595 pasien anak, terdapat 323 (54,29\%) pasien dengan penyakit kulit non-infeksi.

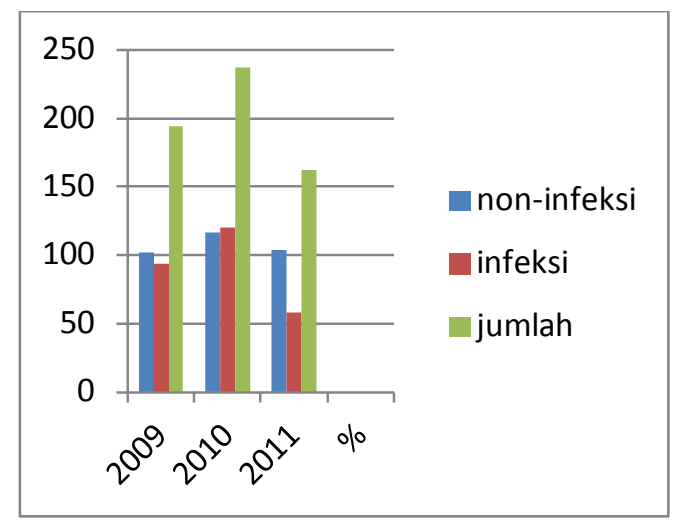

Gambar 1.Jumlah pasien anak Periode Januari 2009-Desember 2011 
Table 1.Distribusi kelompok Penyakit Kulit non-infeksi anak berdasarkan tahun Periode Januari 2009-Desember 2011

\begin{tabular}{llcccc}
\hline No & Kelompok penyakit kulit & 2009 & 2010 & 2011 & $\%$ \\
\hline 1 & Dermatitis & 83 & 72 & 81 & $236(73,07)$ \\
2 & Kelainan papuloskuamosa & 3 & 21 & 15 & $39(12,07)$ \\
3 & Kelainan pigmen & 7 & 7 & 5 & $19(5,88)$ \\
4 & Sindrom hipersensitivitas & 1 & 6 & 3 & $10(3,10)$ \\
5 & Gigitan serangga & 7 & 1 & 1 & $9(2,79)$ \\
6 & Tumor kulit & 3 & 1 & 3 & $7(2,17)$ \\
7 & $\begin{array}{l}\text { Kelainan kelenjer sebasea } \\
\text { dan keringat }\end{array}$ & 0 & 2 & 0 & $2(0,62)$ \\
8 & Kelainan rambut & 1 & 0 & 0 & $1(0,30)$ \\
\hline & Jumlah & 105 & 110 & 108 & $323(100 \%)$ \\
\hline
\end{tabular}

Kelompok penyakit Kulit non-infeksi terbanyak adalah dermatitis sebanyak 236 pasien (73,07\%), kelainan papuloskuamosa 39 pasien (12,07\%), kelainan pigmen 19 pasien (5,88\%), sindrom hipersensitivitas 10 pasien $(3,10 \%)$, gigitan serangga 9 pasien $(2,79 \%)$.

Table 2.Distribusi kelompok penyakit kulit non-infeksi anak menurut usia Periode Januari 2009-Desember 2011

\begin{tabular}{llcccc}
\hline No & Kelompok penyakit kulit & $<1$ tahun & $\begin{array}{c}1-4 \\
\text { tahun }\end{array}$ & $\begin{array}{c}5-14 \\
\text { tahun }\end{array}$ & $\%$ \\
\hline 1 & Dermatitis & 30 & 71 & 135 & $236(73,07)$ \\
2 & Kelainan papuloskuamosa & 1 & 5 & 33 & $39(12,07)$ \\
3 & Kelainan pigmen & 2 & 4 & 13 & $19(5,88)$ \\
4 & Sindrom hipersensitivitas & 0 & 6 & 4 & $10(3,10)$
\end{tabular}




\begin{tabular}{llcccc}
5 & Gigitan serangga & 0 & 6 & 3 & $9(2,79)$ \\
6 & Tumor kulit & 3 & 2 & 2 & $7(2,17)$ \\
7 & $\begin{array}{l}\text { Kelainan kelenjer sebasea } \\
\text { dan keringat }\end{array}$ & 1 & 1 & 0 & $2(0,62)$ \\
8 & Kelainan rambut & 0 & 0 & 1 & $1(0,30)$ \\
\hline & Jumlah & $37(11,46)$ & $95(29,41)$ & $191(59,13)$ & $323(100 \%)$ \\
\hline
\end{tabular}

Kelompok usia penyakit kulit non-infeksi anak terbanyak adalah kelompok 5-14 tahun sebanyak 191 (59,13\%).

Table 3.Distribusi kelompok penyakit kulit non-infeksi anak berdasarkan jenis kelamin Periode Januari 2009-Desember 2011

\begin{tabular}{llccc}
\hline No & Kelompok penyakit kulit & Laki laki & perempuan & $\%$ \\
\hline 1 & Dermatitis & 113 & 123 & $236(73,07)$ \\
2 & Kelainan papuloskuamosa & 20 & 19 & $39(12,07)$ \\
3 & Kelainan pigmen & 8 & 11 & $19(5,88)$ \\
4 & Sindrom hipersensitivitas & 7 & 3 & $10(3,10)$ \\
5 & Gigitan serangga & 5 & 4 & $9(2,79)$ \\
6 & Tumor kulit & 2 & 5 & $7(2,17)$ \\
7 & Kelainan kelenjer sebasea dan & 0 & 2 & $2(0,62)$ \\
& keringat & & & $1(0,30)$ \\
9 & Kelainan rambut & 1 & 0 & $323(100 \%)$ \\
\hline
\end{tabular}

Distribusi jenis kelamin memperlihatkan pasien laki-laki sebanyak 156 (48,30\%) dan pasien perempuan sebanyak 167 (51,70\%). 


\section{BAHASAN}

Dari sejumlah 595 kunjungan pasien anak kepoliklinik kulit dan kelamin RSUP Prof. Dr. R. D. Kandou Manado didapati 323 (54,29\%) pasien anak dengan penyakit kulit non-infeksi. Terlihat bahwa yang terbanyak adalah kasus dermatitis sebanyak 236 (73,07\%) pasien. Lima kelompok terbanyak adalah dermatitis, kelainan papuloskuamosa, kelainan pigmen, sindrom hipersensitivitas, gigitan serangga. Urutan pertama ini sama dengan Budiastuti K di RSUD. Dr. Soetomo Surabaya (1992) dan Pandelake HE di RSUD Gunung Wenang Manado (1992), Ginting SR dkk. Di RS.Pirngadi Medan (1994), Nasution AR di RSUD Dr. Soedarso Pontianak (1995). Dan Suhariyanto B di RSUD Dr. Soebandi Jember (2004). ${ }^{4,5}$

Dermatitis di Makasar, Semarang terdapat pada urutan kedua, sedangkan di Jakarta dan Medan terlihat pada urutan keempat tetapi di Manado berada pada urutan teratas. Perbedaan urutan ini kemungkinan disebabkan oleh karena kondisi daerah yang berbeda serta tahun penelitian yang tidak sama.

Kelompok usia penyakit kulit noninfeksi terbanyak adalah kelompok 514 tahun (59,13\%). Keadaan ini sama dengan Budiastuti K di Surabaya (1992), Pandaleke HE di RSUD Gunung Wenang Manado (1992), Ginting SR dkk. Di Medan (1994), Suhariyanto B di Jember (2004). Namun berbeda dengan Nasution AR di Pontianak, kelompok usia terbanyak adalah 1-4 tahun. ${ }^{6}$
Distribusi jenis kelamin memperlihatkan pasien laki-laki sebanyak 156 (48,30\%) dan pasien perempuan sebanyak 167 (51,70\%). Rasio laki-laki dan perempuan $1: 1,3$, berarti tidak terlihat perbedaan yang mencolok.

\section{SIMPULAN}

Dari 595 pasien anak, terdapat 323 pasien $(54,29 \%)$ dengan penyakit kulit non-infeksi. Lima kelompok penyakit kulit non-infeksi terbanyak adalah dermatitis, kelainan papuloskuamosa, kelainan pigmen, sindrom hipersensitivitas dan gigitan serangga. Kelompok usia penyakit kulit noninfeksi anak terbanyak adalah 5-14 tahun dan rasio laki-laki :perempuan adalah $1: 1,3$.

\section{UCAPAN TERIMA KASIH}

Ditujukan kepada Dr. Renate T. Kandou, $\operatorname{SpKK}(\mathrm{K})$ dan Dr. Nurdjannah J. Niode, SpKK selaku penguji skripsi yang telah memberikan masukan dan saran dalam penulisan serta kepada semua pihak yang secara langsung maupun tidak langsung telah memberikan ide atau gagasan dalam penulisan ini.

\section{DAFTAR PUSTAKA}

1. Abdoerrachman $\mathrm{MH}$, Affandi $\mathrm{MB}$, Agusman S, Alatas H, Dahlan A, Aminullah A, et al. Ilmu Kesehatan anak. Fakultas Kedokteran Universitas Indonesia. Jakarta, 1985. H: 229-232.

2. Boediardja SA, Panduan Praktis Morfologi dan Terminologi penyakit kulit. Fakultas Kedokteran Indonesia. Jakarta, 2011. H:7 
3. Djuanda A, Hamzah M, Aisah S. Ilmu Penyakit Kulit dan Kelamin FK UI, $5^{\text {th }}$.ed: Jakarta, 2011.

4. Pandaleke HE, Kartini A, Gaspersz S, Jackqueline S. Pola penyakit kulit non-infeksi pada anak. Kumpulan makalah symposium dermatologi anak, Manado, 2009. H:302-305.

5. Budiastuti K, Samsul Harun E, Barakbah J. Pola penyakit kulit pada anak di RSUD Dr. Soetomo Surabaya. Berkala Ilmu Penyakit Kulit dan Kelamin FK Universitas Airlangga. 1994:6/1:23-29.

6. Pandaleke HE, Warouw WF. Insiden penyakit kulit pada anak di RSUD. Gunung Wenang Manado. Kumpulan Naskah Ilmiah KONAS VII PERDOSKI Bukittinggi. 1992: 4149. 